\title{
НАЦІОНАЛЬНИЙ ПОРЯДОК ЗАХИСТУ ПРАВ НА ГЕОГРАФІЧНЕ ЗАЗНАЧЕННЯ ТА ПЕРСПЕКТИВИ ЙОГО УДОСКОНАЛЕННЯ В УКРАЇНІ
}

Анотація. В умовах сучасної економічної ситуації та жорсткої ринкової конкуренції індивідуалізація виготовленої продукції забезпечуеться не лише шляхом їі позначення торговельними марками чи знаками, а суттеву роль відіграють особливі властивості та якості товару, безпосередньо пов'язані з географічним місцем його виготовлення. Будь то природні чи людські фактори, характерні для відповідного географічного місця розташування, зумовлюють надання виробленим продуктам особливих параметрів, що забезпечують їх відмежування від однакової (однорідної) продукції інших виробників. Сьогочасний споживач при виборі товару звертає увагу не просто на зовнішню обгортку, рекомендації чи рекламну кампанію, а також цікавиться географічним джерелом його походження. Поступово виникає потреба правової охорони географічних назв, що використовуються у позначенні товару, яка забезпечуеться цивільним законодавством шляхом утворення комплексу правових норм про географічне зазначення.

Ключові слова: інтелектуальна власність, географічне зазначення, походження товару, захист прав, судовий розгляд.

Sych Karina, Zolota Lesia Sumy State University

\section{NATIONAL PROCEDURE FOR PROTECTION OF RIGHTS TO GEOGRAPHICAL INDICATION AND PROSPECTS FOR IMPROVEMENT IN UKRAINE}

Summary. In the current economic situation and fierce market competition, the individualization of manufactured products is ensured not only by marking them with trademarks or signs, but also play a significant role in the special properties and qualities of the product directly related to its geographical location. Whether natural or human factors, characteristic of the respective geographical location, determine the provision of manufactured products with special parameters that ensure their separation from the same (homogeneous) products of other manufacturers. Today's consumer when choosing a product pays attention not only to the outer wrapper, recommendations or advertising campaign, but also interested in the geographical source of its origin. Gradually, there is a need for legal protection of geographical names used in the designation of goods, which is provided by civil law through the formation of a set of legal norms on geographical indications. In our country, only a system of protection of intellectual property, including geographical indications, and the protection system itself is still far from perfect, however, the role of intellectual property in modern conditions should not be underestimated, because in the near future production will only be a means of realization achievements of intellectual activity. In addition, the current national legislation on geographical indications contains many inconsistencies and gaps, which in itself is unacceptable, so there is a need to bring such legislation in line with both domestic regulations and in accordance with the content of international law. Therefore, there is a need to refer to the experience of foreign countries and to explore the advantages and disadvantages of the international legal system for the protection of geographical indications.

Keywords: intellectual property, geographical indication, origin of goods, protection of rights, litigation.

$\Pi^{2}$ остановка проблеми. У нашій державі лише встановлюеться система охорони об'єктів інтелектуальної власності, у тому числі географічних зазначень, а сама система захисту $є$ ще далекою від досконалості, проте, роль інтелектуальної власності в сучасних умовах не варто знецінювати, адже в недалекому майбутньому виробництво стане лише засобом реалізації досягнень інтелектуальної діяльності.

Аналіз останніх досліджень і публікацій. При дослідженні поставлених у статті завдань були частково опрацьовані та використані наукові досягнення фрахівців у різних галузях права. Зокрема: О. Андрощук, М. Архипова, А. Афрян, А. Кодинець, Н. Мчедлішвілі, А. Нерсесян, О. Орлюк, О. Святоцький.

Виділення невирішених раніше частин загальної проблеми. Розгляд та вирішення спорів 3 приводу засобів індивідуалізації нерідко потребуе спеціальних профресійних знань та практичних навичок, які часто відсутні у суддів, внаслідок цього багато прийнятих рішень скасовуються вищими інстанціями. Тому слід підтримати пропозиції вітчизняних вчених щодо необхідності формування спеціалізованих судів, предметом розгляду яких будуть спори про право інтелектуальної власності. Нині в деяких судах функціонують окремі підрозділи, які спеціалізуються на розгляді даної категорії спорів, однак, їх діяльність не забезпечує повною мірою ефективного вирішення ціеї проблеми.

Формулювання цілей статті. Метою даної статті $є$ дослідження нащіонального порядку захисту прав на географічні зазначення як актуального об'єкта інтелектуальної власності та перспектив його удосконалення.

Виклад основного матеріалу дослідження. "Оскільки національна система захисту прав на географрічне зазначення $є$ підсистемою захисту цивільних прав взагалі та прав на об'єкти інтелектуальної власності зокрема, їй притаманні загальні риси української системи правового захисту» [1] - проголошуе видатна вчена M.I. Архипова. 
У вітчизняній цивілістичній доктрині найбільш розповсюджено розуміння захисту як можливості уповноваженої особи застосувати заходи правоохоронного характеру для поновлення свого порушеного чи оспорюваного права. Найбільш послідовно ця позиція відображена у працях В.П. Грибанова. Відповідно до даного підходу, «право на захист не обмежуеться лише застосуванням державою заходів примусового характеру, а пов'язуеться, насамперед, з діяльністю самого суб'єкта щодо поновлення порушеного права та припинення дій, які його порушують» [2].

Таке теоретичне тлумачення захисту видається найбільш переконливим, оскільки: по-перше, дозволяе охопити поняттям захисту весь спектр можливих фрорм його здійснення, включаючи самозахист та захист права юрисдикційними органами; по-друге, грунтуеться на прояві ініціативи самого суб'єкта приватноправових відносин, права якого порушені чи яким створюеться загроза порушення; по-трете, відображає специфіку цивільно-правових норм та випливає з методу приватного права, невід'ємною ознакою якого є ініціативно-диспозитивний характер виникнення правових зв'язків між учасниками цивільних правовідносин.

Кандидат юридичних наук А.О. Кодинець стверджуе: «На відміну від речових та особистих немайнових прав, у сорері захисту яких існують широкі можливості до застосування незаборонених законом засобів протидії самою особою, у межах права інтелектуальної власності загалом та засобів індивідуалізащії зокрема така діяльність суттево обмежена характером прав, щодо яких вчинене чи на які посягає правопорушення» [3].

Таким чином, як приклад самозахисту порушених прав на географічні зазначення можна навести лише:

- публічну заяву потерпілого про те, що конкретна фізична чи юридична особа незаконно користуеться тотожним чи подібним географічним зазначенням;

- звернення потерпілого до правопорушника з вимогою припинення незаконного використання географічного зазначення чи схожих 3 ним позначень в претензійному порядку.

Більш широко для захисту прав на географічні зазначення застосовуються юрисдикційні способи захисту у загальному (судовому) та спеціальному (адміністративному) порядках. Стаття 16 ЦК України встановлюе невичерпний перелік способів захисту, які використовуються судом.

Втім, варто зазначити, що не всі способи мають однакове значення для судового захисту порушеного чи оспорюваного права на географрічне зазначення. Оскільки право на використання кваліфікованого зазначення походження товарів закріплюеться державною реєстрацією, основним способом його захисту від конфрліктуючих позначень буде вимога про визнання незаконним акта органу державної влади. 3 іншого боку, для захисту џього права не притаманно використання такого способу, як примусове виконання обов'язку в натурі, оскільки його об'єктом є нематеріальне благо. Тому до основних способів судового захисту прав на географічні зазначення можна віднести:

- визнання права;
- відновлення становища, яке існувало до порушення права;

- визнання незаконним правового акта органу державної влади;

- відшкодування збитків, компенсація моральної шкоди;

«Крім загальних способів захисту, у межах кожного самостійного інституту можна виокремити додаткові спеціальні захисні механізми, які використовуються для поновлення даної групи прав у випадку їх порушення чи оспорення» [4], - наголошує видатний вчений Р.Б. Шишка. Так, для захисту прав інтелектуальної власності суд може вжити наступні заходи, передбачені статтею 432 Цивільного кодексу України:

- вживання негайних заходів щодо попередження порушенню права інтелектуальної власності та збереження відповідних доказів;

- зупинення пропуску через митний кордон України товарів, імпорт чи експорт яких здійснюється 3 порушенням права інтелектуальної власності;

- вилучення 3 цивільного обороту товарів, виготовлених або введених у цивільний оборот 3 порушенням права інтелектуальної власності та знищення таких товарів;

- вилучення з цивільного обороту матеріалів та знарядь, які використовувалися переважно для виготовлення товарів 3 порушенням права інтелектуальної власності або вилучення та знищення таких матеріалів та знарядь;

- застосування разового грошового стягнення замість відшкодування збитків за неправомірне використання об'єкта права інтелектуальної власності. Розмір стягнення визначається відповідно до закону з урахуванням вини особи та інших обставин, що мають істотне значення;

- опублікування в засобах масової інформації відомостей про порушення права інтелектуальної власності та зміст судового рішення щодо такого порушення. (вилучити з цивільного обороту товари, що виготовлені з порушенням права інтелектуальної власності, знаряддя та матеріали, які використовувалися для їх виготовлення, застосувати разове грошове стягнення тощо).

Так як географрічне зазначення, безумовно, належить до об'єктів права інтелектуальної власності, на нього розповсюджуються всі вищевказані способи судового захисту. Крім того, «згідно зі спеціальним законом, суди відповідно до їх компетенції розв'язують спори про правомірність реєстрації кваліфрікованого зазначення походження товару, встановлення фракту використання кваліфрікованого зазначення походження товару, порушення прав власника свідоцтва про реестрацію права на використання кваліфікованого зазначення походження товару, компенсації» [5], - уточнюе відома дослідниця в галузі цивільного права О.В. Дзера.

При цьому дощільно відмітити, що розгляд та вирішення спорів з приводу засобів індивідуалізації нерідко потребуе спеціальних профресійних знань та практичних навичок, які часто відсутні у суддів, внаслідок цього багато прийнятих рішень скасовуються вищими інстанціями. Тому слід підтримати пропозиції вітчизняних вчених щодо необхідності фрормування спеціалізованих судів, предметом розгляду яких будуть спори про право інтелектуальної власності [6]. 
Нині в деяких судах фрнкціонують окремі підрозділи, які спеціалізуються на розгляді даної категорії спорів, однак, їх діяльність не забезпечуе повною мірою ефективного вирішення ціеї проблеми.

Розглядаючи національну систему захисту прав на географрічні зазначення, неможливо оминути поза увагою питання їх кримінальноправової охорони. Згідно з нормами статті 229 Кримінального кодексу України, «незаконне використання кваліфікованого зазначення походження товару, або інше умисне порушення права на цей об'єкт, якщо це завдало матеріальної шкоди у значному розмірі, караеться штрафом від одніеї тисячі до двох тисяч неоподатковуваних мінімумів доходів громадян 3 конфіскаціею і знищенням відповідної продукції та знарядь і матеріалів, які спеціально використовувалися для її виготовлення.

У разі якщо злочинцем е службова особа, яка скористалася службовим становищем або організована група, або якщо він завдав матеріальної шкоди в особливо великому розмірі, призначається покарання у вигляді штрафу в розмірі від десяти тисяч до п'ятнадцяти тисяч неоподатковуваних мінімумів доходів громадян з позбавленням права обіймати певні посади чи займатися певною діяльністю на строк до трьох років або без такого та з конфіскаціею і знищенням відповідної продукції та знарядь і матеріалів, які спеціально використовувалися для ї̈ виготовлення» [7].

Разом з тим, правник В.Б. Харченко наголошуе: «Суспільна небезпечність (шкідливість) зазначених посягань полягае не стільки у спричиненні прямої матеріальної шкоди або втрати вигоди, а і у заподіянні шкоди іміджу, престижу, репутації та конкретним обсягам рекламних заходів і акцій. Ми вважаемо, що більш обюрунтованим і доцільним є визначення суспільно небезпечних наслідків не за розміром матеріальної шкоди, а за істотністю такої шкоди. Таке визначення суспільно небезпечних наслідків охоплювало б не тільки пряму дійсну шкоду та втрачену вигоду, а і заподіяння шкоди діловій репутащії, престижу та іміджу володільців прав на географрічні зазначення).

Крім того, при характеристиці суспільно небезпечного діяння, що утворюе порушення права інтелектуальної власності на географрічне зазначення, було б «доцільно застосовувати бланкову диспозицію, оскільки нормами цивільного та господарського законодавства визначаються не тільки інциденти порушення цього права, а і зміст таких порушень» [8].

Висновки та перспективи. Розглянувши відомі засоби захисту для географічних зазначень, можна зробити обгрунтований висновок, що вони, за словами Г. Андрощука: «визначаються двома основними лініями. Одна спрямована на захист споживачів від використання географрічних зазначень, що вводять в оману, а інша - на захист власників колективного престижу фірми, пов'язаного з географічними зазначеннями, від введення в оману, яке призводить до незаконного привласнення цього престижу». Разом вони складають цілісну систему захисту суб'єктивних прав на географічні зазначення, яка в цілому відповідае міжнародним вимогам, але потребуе подальшого вдосконалення.

\section{Список літератури:}

1. Архипова М.І. Цивільно-правова охорона географічних зазначень в Україні : авторед. дис. ... канд. юрид. наук : спец. 12.00.03. Київ, 2006. С. 13.

2. Грибанов В.П. Осуществление и защита гражданских прав. Москва : Статут, 2001. С. 107.

3. Кодинець А.О. Реформування системи охорони інтелектуальної власності в умовах евроінтеграційних процесів в Україні. Вісник Запорізького національного університету. Юридичні науки. 2014. № 4(2). С. 65-72.

4. Шишка Р.Б. Охорона прав суб'єктів інтелектуальної власності у цивільному праві України : автореф. дис. д.ю.н. : спец. 12.00.03. Одеса, 2004. С. 21.

5. Дзера О.В., Кузнецова Н.С., Майданик Р.А. Цивільне право України. Загальна частина. Київ : Юрінком Інтер, 2010. С. 317.

6. Дорошенко Л., Орлюк Е. Зачем менять подсудность споров? Юридическая практика. 2005. № 49. С. 8-12.

7. Кримінальний кодекс України від 05 квітня 2001 року. Відомості Верховної Ради Украӥни. 2001. № 25-26. Ст. 131.

8. Харченко В.Б. Кримінально-правова охорона комерційного найменування, торговельної марки і географічного зазначення за законодавством України. Юридична Україна. 2010. № 6. С. 107.

9. Андрощук Г. Географічні зазначення: характер прав, існуючі системи охорони та захист (частина 1). Інтелектуальна власність. 2005. № 11. С. 13.

\section{References:}

1. Arhypova M.I. (2006) Cyvilno-pravova oxorona geografichnyh zaznachen v Ukrayini [Civil law protection of geographical indications in Ukraine] (PhD Thesis), Kyiv, p. 13.

2. Grybanov V.P. (2001) Osushhestvlenye y zashchyta grazhdanskyh prav. Moscow: Statut, p. 107.

3. Kodynecz A.O. (2014) Reformuvannya systemy oxorony intelektualnoyi vlasnosti v umovax yevrointegracijnyx procesiv v Ukrayini. Visnyk Zaporizkogo nacionalnogo universytetu. Yurydychni nauky, vol. 4(2), pp. 65-72.

4. Shyshka R.B. (2004) Oxorona prav subyektiv intelektualnoyi vlasnosti u cyvilnomu pravi Ukrayiny [Protection of the rights of intellectual property subjects in the civil law of Ukraine] (PhD Thesis), Odesa, p. 21.

5. Dzera O.V., Kuznyeczova N.S., Majdanyk R.A. (2010) Cyvilne pravo Ukrayiny. Zagalna chastyna. Kyiv: Yurinkom Inter, p. 317.

6. Doroshenko L., Orlyuk E. (2005) Zachem menyat podsudnost sporov? Yurydycheskaya praktyka, vol. 49, pp. 8-12.

7. Kryminalnyj kodeks Ukrayiny vid 05 kvitnya 2001 roku. Vidomosti Verhovnoyi Rady Ukrayiny, vol. 25-26. st. 131.

8. Kharchenko V.B. (2010) Kryminalno-pravova ohorona komercijnogo najmenuvannya, torgovelnoyi marky i geografichnogo zaznachennya za zakonodavstvom Ukrayiny. Yurydychna Ukrayina, vol. 6, p. 107.

9. Androshchuk G. (2005) Geografichni zaznachennya: kharakter prav, isnuyuchi systemy ohorony ta zaxyst (chastyna 1). Intelektualna vlasnist, no. 11, p. 13. 